\title{
APPLICATION OF NATURAL LAW THEORY (NATURAL RIGHT) TO PROTECT THE INTELLECTUAL PROPERTY RIGHTS
}

\author{
Prasetyo Hadi Purwandoko; M. Najib Imanullah \\ Faculty of Law, University of Sebelas Maret \\ Email: omprasetyohp@gmail.com; imanulahnajib@yahoo.com.
}

\begin{abstract}
The theory of natural law is usually used as a moral and philosophical foundation in order to protect the individuals property rights of Intellectual Property (IP). Philosophically, the protection of Intellectual Property Rights (IPR) can not be separated from the dominant thought that emphasizes the doctrine of natural human factors research. This study is legal research by using law and historical approach. The analysis of primary data is qualitatively through internal valuing to obtain a complete understanding (verstehen), while the secondary data such as law material is analyzed using hermeneutics (interpretation), content analysis and deductive method. The result shows that in respect of the development of the theory of natural law, there are four dominant theory of natural law to examine IP namely utilitarian theory, labor theory, personality theory, and social-planning theories. Moral doctrine which is based on natural law was adopted by the IPR regime to protect the individual owners of IPRs in order to that rights would not be violated by others. The natural law theory (the natural right) is still relevant to be used as a moral and philosophical foundation for the protection of IPR, as an individual property rights.
\end{abstract}

Keywords: Intellectual Property, Intellectual Property Rights, traditional cultural expression, Protection

\section{A. INTRODUCTION}

In modern times it can be understood that economic globalization and free trade have affected very large changes to the legal field. Countries in the world are involved with economic globalization and free trade, both developed and developing even the least developed countries should standardize the laws in their economic activities. Economic globalization are increasingly being developed based on the principle of trade liberalization or free trade which others who have had an impact on the laws of each country involved in economic globalization and free trade. Economic globalization and free trade are unavoidable and must be followed because of economic globalization and the free trade evolved through negotiations and agreements (John Braithwaite and Peter Drahos, 2000: 24-23).

One of the economic globalization that affects the legal system and the economy is Intellectual Property Rights (IPR). This is a trend which is then used by the public to bind and to protect the rights of intellectual. Issues in the field of IPR is a very important issue as it relates 
to international trade and economic growth of a country. Technological innovation as well as an increase in economic power is necessary for the growth and development of industrial society. Technological innovation can bring prosperity to people's lives, and encourage the growth of technology development community.

\section{B. PROBLEM STATEMENT}

Based on the brief elaboration in above introduction, the issues discussed in this paper is whether the theory of natural law (the natural right) is still relevant to be used as the basis of legal protection of Intellectual Property?

\section{RESEARCH METHODS}

This study is legal research by using the statute and historical approach. The primary data

analysis techniques is qualitatively through internal valuing to obtain a complete understanding (verstehen), while the secondary data such as law material was analyzed using hermeneutics (interpretation), content analysis, and deductive method.

\section{RESEARCH RESULT AND DISCUSSION}

\section{Terminology of Intellectual Property Rights}

Intellectual Property Rights (IPR) is a right derived from intellectual property (IP), which can be described as property rights arising out of or born as a human intellectual abilities. The intellectual works in the fields of science, art, literature or technology, are born with the sacrifice of energy, time and even cost. The existence of these sacrifices are resulting work to be valuable. When coupled with the economic benefits that can be enjoyed, then the inherent economic value grows conception of wealth (property) to the intellectual works. For the business world, the works are regarded as assets of the company. Thus, this right is born because of human intellectual abilities.

Terminology development of IPR, which previously known as Industrial Property Rights, then there is a mention of Industrial Property Rights. There is also a mention of Intellectual Property Rights or IPR in abbreviated. Intellectual Property Rights is derived from the 
Anglo-Saxon legal system literature. In the Netherlands the term was introduced as Intellectuele Eigendomsrecht. In Indonesia, officially for the first time the term of Intellectual Property Rights (IPR) is used as a term equivalent in Law Number 7 of 1994 are used in a variety of the Law governing the types of intellectual property rights following the implementation regulations (adopted in the period end 1980 to end 1990). The 1993 GBHN and 1998 GBHN translated terms such Intellectual Property Rights. However, Law Number 25 of 2000 on the National Development Programme 2000-2004 is a further elaboration Guidelines 1999-2004 translates the term Intellectual Property Rights, IPR abbreviated. The term then in progress since 2000 based on the Ministry of Justice Number M.03.PR.07.10 2000 and also with the approval of the Minister of State for Administrative Reform No.24 / M / PAN / 1/2000 stipulated the use of the term Intellectual Property Rights (IPR) , In 2011 President Susilo Bambang Yudhoyono (in http: // www. Detiknews.com / read / 2011/04/26/134737/1625819/10 /) does not agree with the term Intellectual Property. It is delivered in the worldwide IPR Warning Event at the State Palace, 2011. Further developments, pursuant to Presidential Decree Number 44 of 2015 the change in nomenclature of the Directorate General of Intellectual Property Rights (IPR) transformed into the Directorate of Intellectual Property (IP), with the reasons for institutions in other countries are dealing with the field of intellectual property. In this paper the author uses the term Intellectual Property (IP) and the Intellectual Property Rights (IPR).

IP definition according to the World Intellectual Property Organization (WIPO): "Very broadly, means the legal intellectual property rights result from intellectual actitivity roomates in the industrial, scientific, literary and artistic fields.". Furthermore, the Convention of the World Intellectual Property Organization (WIPO), IPR (IPR) means "Intellectual property right is defined as" intellectual property shall include the rights Relating lo: leterary, artistic and scientific works, inventions in all fields of human endeavor, scientific discoveries, industrial designs, trademarks, service makrs, and commercial names and designations, protection against unfair competition and all other rights from intellectual activity in the industrial, scientific or artistic fields "(Article 2).

Furthermore, the TRIPS Agreement / World Trade Organization declared:

"Intellectual property is defined as" The term intellectual property "Refers to all categories of 
intellectual property that are the subject of section 1 through 7 of Part II" (Article 1 (2)). And ..., copyright and related rights (Section 1), trademarks (Section 2), geographical indications (Section 3), industrial designs (Section 4), patents (Section 5), layout designs of integrated circuits (Section 6), and protection of undisclosed information (Section 7) are stipulated in the Agreement.

In Japan IP means (Sadayuki Hosai in Prasetyo Hadi Purwandoko, 2010: 3): The world "intellectual property" is usually used to refer generallyu to mental works created through intellectual human activities, such as industrial property, Including "a patent, a utility models, a design and a trademark," and copyright.

Thus, IP is everything that is created through the intellectual activity of a person. Furthermore, IPR can be interpreted as property rights derived from intellectual abilities expressed in the form of the creation of the result of creativity through a variety of fields, such as science, technology, art, literature, design and so on (See .Akira Okawa, 1996:1, Muhamad Djumhana dan R. Djubaedillah, 1996: 16 , Ok Saidin, 2004: 9, Richard Burton Simatupang, 1996: 84-85, Adami Chazawi, 2007: 2, Rachmadi Usman, 2003: 2, Muhammad Ahkam Subroto \& Suprapedi, 2008: 14, Dicky R. Munaf dalam Budi Agus Riswandi \& Siti Sumartiah,2006:.3). Elsi Kartika Sari and Advendi Simanunsong interpret IPRs as "... the rights arising from the ability to think or process to think that producing a product or process that is useful to humans. In the law of IPR is a treasure ... which has the object of intellectual objects, ie objects that intangible immaterial ...". According to Graham Dutfield," IPRs are legal and institutional devices to protect creations of the mind such as inventions, works of art and literature, and designs. Also they include marks on products to indicate Reviews their difference from Similar ones sold by competitors " (Dutfield, G., 2003: 1) . Furthermore, Zaid Hamzah in his book entitled "Intellectual Property Law \& Strategy" reveals (Zaid Hamzah.,2007:19- 21):

"Intellectual Property is society's recognition of intellectual efforts. It is a monopoly granted in exchange for the contribution of intellectual creation to the society. It is an intangible property. The use of IP by third party does not disprove the owner of his right of enjoyment. As such, an IP right is a right to restian others from using the right. The extent of this right is dependent upon the scope of the ablity granted by the law to restrain its us. The 
wider the scope given, the greater the monopoly has an IP owner. An IPR is a proprietary right roomates a person may exert over the use of his own intelligence. In so exerting this right, the person claims for himself a basic to protect his intelligence from being used by other without his permission. Through the growth and evolvement of law, this tight has Become enforceable under the law of IPRs almost globally".

Meanwhile, Aaron Schwabach refer to it as (Schwabach, A., 2007: 1).: "... the intangible but legally recognized right to property in the products of one's intellect. Intellectual property rights allow the originator of certain ideas, inventions, and expressions to exclude others from using Reviews those ideas, inventions, and expressions without permission "IPR is a system that gives appreciation to the inventors, designers, creators and holders of other intellectual works. It is nothing but an incentive (and of course compensation) for the growth of the works that are useful and much needed by the public (Read A. Zen Umar Purba., 2001/October 17 - 19, 2002/18 February and, 29 January, 2013/20 April 2013). Technological innovation as well as an increase in economic power is necessary for the growth and development of industrial society. Technological innovation can bring prosperity to people's lives, and encourage the growth of technology development community (A. Zen Umar Purba, 2001/20 November). According to Don Tapscot (Don Tapscot in Andy Noorsaman Sommeng, 2002:/21 Oktober) IPR described as follows. The new economy is a knowledge economy and the key assets of every firm become intellectual assets. In the New York Times declared, Intellectual Property has been changed from the fields of law and business are deserted become one engine driving the high-tech economy (New York Times, 9 April 1999). IPR development is essentially a development of human resources ("HR"). It is caused by the IPR dealing with product and process related though human thought. The development of the IPR system is expected to be developed also human Resources, especially the culture of innovative and inventive. It is vitally connected with the fact that, despite the wealth or natural resources abound, we are still "so-so" only even backwards, and growing poverty (A.Zen Umar Purba, 2001/ 7 November). It is appropriate editorial of The Washington Post, 28 April 2001, which states: "... if there is one lesson in the past half century of economic development, it is that natural resources do not power economies, human resources do". It can briefly be interpreted that the Human Resources (potentially 
generate intellectual property) is more important than natural resources.

Economists for years have tried to give an explanation of their most economies can thrive, there is not. It was generally agreed that IPRs play an important role in the current economic growth. The accumulation of knowledge is the driving force for economic growth. For a country that wants to increase its economic growth, the economic policies formulated should encourage investment in research, development and subsidize programs for human resource development (Kamil Idris dalam Prihaniwati, 2004/ 28 September 2). The existence of IPR in the relationships between people and between countries is something that can not be denied. IPR also is something given and inherent in an industrial society or being led to it. Its presence always follow the dynamic development of society itself. Similarly, the community and the nation of Indonesia are inevitably intersect and engage directly with IPR issues (http//:www.dgip.go.id [15 April 2013]).

IPR as a right derived from the results of human intellectual ability, should receive adequate legal protection. Mieke Komar and Ahmad M. Ramli suggested several reasons for IPR protection, namely (See. Mieke Komar dan Ahmad M. Ramli, 1998: 21 ): First, because of the rights granted to an inventor in the field of science, art and literature or inventor in the field of new technology that involves an inventive step is a form of giving a reward and recognition the success of the man in the birth of his innovative works. Secondly, IPR protection system that is easily accessible to other parties, for example, can put forward a patent that is open. The inventor is obliged to elaborate on these findings in detail, which allows others can learn or implement the invention. To that end, is a reasonable and granting an exclusive right to an inventor for a period of time to master and perform exploitation of his invention. Third, IPR is a creation or invention that is pioneering could open the possibility of other parties to further develop the invention produced by the inventor. It is therefore fundamental discoveries must be protected though it may not be protected under patent law regime, can be categorized as a trade secret or confidential information.

Economists have tried to give an explanation of their most economies can thrive for years, there is not. It was generally agreed that IPRs play an important role in the current economic growth. The accumulation of knowledge is the driving force for economic growth. 
For a country that wants to increase its economic growth, the economic policies formulated should encourage investment in research, development and subsidize programs for human resource development. The existence of IPR in the relationships between people and between countries is something that can not be denied. IPR also is something given and inherent in an industrial society or being led to it. Its presence always follow the dynamic development of society itself. Similarly, the community and the nation of Indonesia that inevitably intersect and engage directly with IPR issues.

IPR is not easily defined. However, of these terms can be seen that these rights are rights that come from one's intellectual property. Intellectual property rights have a very broad scope .. Lionel Bentley and Brad Sherman stated that "Intellectual property law creates property rights in a wide and diverse range of things from novels, computer programs, films, television broadcasts, and performances, through to dress designs, pharmaceuticals, genetically modified animals and plants (Lionel Bently \& Brad Sherman, 2004:1). Furthermore, WIPO (World Intellectual Property Organization) divide IP into two categories: industrial property and copyright, which stated: Intellectual property is divided into two categories: Industrial property, the which includes inventions (patents), trademarks, industrial designs, and geographic indications of source; and Copyright, the which includes literary and artistic works such as novels, poems and plays, films, musical works, artistic works such as drawings, paintings, photographs and sculptures, and architectural designs. Rights related to copyright include Reviews those of performing artists in their performances, producers of phonograms in their recordings, and Reviews those of broadcasters in their radio and television programs.

Thus, crimped, IPR as a translation of Intellectual Property Rights (IPR), according to WIPO (the World Intellectual Property Organization) broadly covers two branches, namely:

1) The Copyright, and

2) Industrial Property Right, consist of:
a) Patents;
b) Mark;
c) IIndustrial Design; and
d) Repression of Unfair Competition Practices. 
IPR classification according to the WIPO is different from the TRIP's Agreement. Based on Chapter II Trade Related Aspects of Intellectual Property Rights, Including Trade in Counterfeit Goods (TRIPs), IPR classified into eight, namely:

1) The Copyright and related rights;

2) Mark;

3) Geographical Indication

4) Industrial Design;

5) Patent

6) Lay Out Design of Integrated Circuit;

7) Trade Secret Protection (Undisclosed Information / Trade Secret); and

8) Repression of Unfair Competition Practices.

In principle, there has been no uniformity among experts / practitioners regarding the classification of IPR, more so now that grouping has been less differentiated power because the works of the intellectual results in the utilization of sometimes overlapping occurs combinations. The same thing was stated by Deborah E bounchoux, stating that basically IPR consists of four types of intellectual property, but often interrelated and related to each other: Intellectual property Generally is Viewed as Comprising four separate but Often overlapping types of property rights: trademarks, copyrights, patents, and trade secrets.

\section{Natural Law Theory and IP Protection}

Initially IP appear as part of human rights. IPR protection can be seen from its history began approximately 3200 years ago. At the time it can be known that the concepts developed in the West today is a chain of influence from earlier traditions. Almost all countries in the Western European civilization inherited the Roman Empire. In the field of law is very powerful influence, the influence of Justinian Codex in European legal tradition very large before the idea of 'state', almost all of Western Europe is part of the Roman Empire so that was very big influence is only natural. Roman building and developing legal concepts such as the inheritor of ancient Greece. Judging from history proved that the Roman is the heir to the glory of ancient Greece (Acient Breek) past the philosophical tradition of 
thought Stoa (Stoicim). Therefore, it is no exaggeration if it is stated that a lot of the concepts of state and law in the Western tradition to draw inspiration from Aristotes and Plato. Then the seeds of the spirit of liberalism and skularisme actually had them get on the Ancient Greek civilization. The modern Western philosophers developed the concepts of the soul liberalism. At that time, the Roman society had its mark on ceramics to show the identity of the author (Granstrand, O., 1999:28).

Awareness of the basic rights of human beings began to emerge from the Western world. IP arrangement arose because of problems faced by the community, in this case the people in the Western world, especially Western Europe and North America. IP issue does not come from the tradition of non-Western societies, including Islamic, Buddhist, and Confucian because there is a cause and a certain background. This does not mean they do not have a relatively advanced civilization that they did not spark the idea of IPR. It should be recognized Chinese, Indian, and Arab civilization had been in the climax of the world ..

Legal protection of private property rights has been a key factor in the growth of capitalism and free market economy. History records of ancient societies show that people recognize the right to control the land and goods, and respected by the government to protect their interests in wealth. As technology changes, the conception of this shift. The legal system of wealth lay in three categories, the first, most people recognize the right of private ownership in personal wealth, which is known by the intangible things; The second, in terms of real wealth, such as land and buildings; and third, the wealth is known as intellectual property (Khaerul Hidayat Tanjung, 2007, .http://khaerulhtanjung.lblogster.Com/filosofi_hak_kekayaan_ intelektual.html.). This concept is attempted used as a rationale in IPR protection. As outlined previously that if the intellectual property requires thought and creativity of the inventor, or creator. Therefore, the right decision by not giving compensation to its owner is an act which can not be justified for violating the moral teachings of the good. This moral foundation that the philosophical theory known as the theory of natural law. In the moral teaching of the doctrine known as "do not steal", or "do not take what is not your right". IP's own conception of legal protection based on the theory. The theory itself is used by experts to facilitate the understanding of the symptoms in the community. In legal theory, the theory is intended to 
facilitate a better understanding of the theoretical globally and provide a global explanation of the symptoms of law (See. Otje Salman and F. Anton Susanto, 2005: 59).

The theory of natural law (the natural right) is usually used as the foundation of moral and philosophical demands to protect the property rights of individuals in the form of intellectual property ( Otje Salman and Anton F. Susanto, 2005: 59) ,The basic idea of this theory is the intellectual property is owned by the creator, thus, be fair if the creator is given protection to any rights attached to the invention (Arthur R. Miller dan Michael H. Davis., 1983: 15).

In philosophy, IPR protection can not be separated from the domination of thought or the Doctrine of Natural Law that emphasizes the human factor, which is then in the modern era can be seen in the provisions of Article 27 paragraph (2) Universal Declaration of Human Rights states that "Everyone has the right to the protection of the moral and material intersts the resulting from any scientific, literary or artistic production of the which he (sic) is the author ".

Moral doctrine which is based on natural law adopted by IPR regimes to provide protection of individual owners of IP so that rights are not violated by others. Indeed, the doctrine of natural law is broader than simply protecting the individual owner of IP because the doctrine was also to be applied to protect other parties, including local and traditional communities over their traditional knowledge. Approach moral foundation upon demand to protect IPRs of this emphasis on honesty and fairness. If a person's attempt to steal without getting prior approval it will be seen as an act of dishonest and unfair. Therefore IP holdings included in human rights as individuals who exercise thought, then naturally the value of communalism must be ignored to recognize and reward individuals

Furthermore, argument on concepts and new IPR regime began in the 18th century. Philosopher who became a figure of IPR development is John Locke (1632-1704). Locke in his book The Second Treatise of Government holds that everything that exists in this world in the beginning is the property of all mankind. However, "everything" itself can not be used directly without obtained and processed first. To be processed, something that exists in nature should be taken first, as animals to be eaten must first be captured and processed by someone (which also means owned by that person). Therefore, Locke stressed the importance 
of giving awards to people who have made "sacrifices" to find and cultivate something that comes from nature in the form of ownership. In addition, each person naturally has the right to himself. Therefore, the results of his work (labor) has added a "personality" into something that has been processed it, as disclosed (Locke, J. 2004: 17-19): ".. yet every man has a" property "in his own 'person'. Nobody has any right to but himself. The 'labor' of his body and the 'work' of his hands, we may say, are properly his. Whatsoever, then, he removes out of the state that Nature hath Provided and left it in, he hath mixed his labor with it, and joined to it something that is his own, and thereby makes it his property."

Later, Justin Hughes (Hughes, J.,1988: 24) in The Philosophy of Intellectual Property, connecting Locke and the problem of IPR protection, stating that the IPR gained through the process of learning / understanding (cognitive), so that even if the "input" that encourage the process of creation is derived from the environment beyond the creator, but the process of "assembling" the creation itself occurred in his mind so no longer pure like the original shape. However, Locke did not agree with excessive ownership over something because it will harm the interests of other people, which means that contrary to the natural law. Therefore, he said, anything can be used as the property as long it fits to the requirement "enough and as good left in common for others"(Hughes, J.,1988:6). When linking context of social life at that time, Locke's view is very closely connected with the desire to challenge empires (the absolute rules) and considered "irresponsible", which dominates the property of various things instead of abilities / talents of individual members of the kingdom itself but only because of the power it has (Hughes, J.,1988:6). It is based on the thinking of the danger the existence of an absolute monarchy to two things, the ability to perform "the capricious incarceration or the arbitrary seizure of property " and that "an absolute Monarchy could claim authority to enforce a particular set of beliefs"(Casson, D.J., 2011: 210). . Such thinking can not be separated from the development of secularism as a result of religious wars that conducted in in Europe for 30 years (1618-1648), which killed about 8 million inhabitants. At that time, the absolute monarchy established itself as the representative of God on earth as the legitimacy of power and control, including the power in terms of ownership of everything. War is then made Locke become influential peson, for refusing to delegate the Lord to the ruler in ownership rights, but considers that all kinds of power 
(including property rights) is based on the individual power over himself, as the above quote. At later date, this understanding will be known by individualism, liberalism spawned (Thirty Years War. http://www.historylearningsite.co.uk/thirty_years_war.htm. $\left[\begin{array}{ll}5 & \text { September }\end{array}\right.$ 2011]).

Other figures in the field of IPR developments are Jean Jacques Rousseau (1712-1778). In his book entitled Du Contrat Social, it is said that: "Every man has naturally a right to everything he needs ..." The analogy he uses is land ownership. Relating this, Rousseau said the terms of the ownership of land, that land has no owner; humans can only control the land area needed; and such ownership shall be accompanied by management on an ongoing basis (Rousseau, J.J., 2003: 13., Mitchell, H.C.,2005: 78-80). In addition, it says also that each individual voluntarily surrendered to the rights and obligations regulated by the state (Keller, B., 2010: dalam Asbach, O. and Schröder, P. (Ed.). :137). This means that rights is actually natural, then the power to recognize the ownership rights grant to the state because it is connected to the power possessed by the state to protect these rights if violated by other party (Rousseau, J.J. 2004: 2-13. http://books.google.co.id/. [26 April 2013]).

"Personality" as described by Locke, then becomes a theory called personality theory, advanced by Georg Wilhelm Friedrich Hegel (1770-1831). According to Hegel, "the individual's will is the core of the individual's existence ... constantly seeking actuality ... and effectiveness in the world". This theory is considered as a reflection of liberty which, according to Hegel should be realized in the form of a work is to be seen clearly. In life, people in the early stages "taking" everything that exists outside of it. Further, humans have the desire (will) to address what has been gained is based on his personal whim. The attitude in the form of a work is, and then of humans is concerned, because it is an expression of the desire in question. If then it is recognized by the community, then the theory that a work is an expression of the identity of the creator becomes legally valid as property rights (Hughes, J.,1988: 28-30). Hegel viewed intellectual property as an "ongoing expression of its creator, not as a free, abandonable cultural object". Relating this, payments made by someone to buy the work of creators considered as an act of recognition of the author as a man of pride and dignity. The same thing applies in the case of IPR creator purchased by another party. This concept later in IPR law known as "moral rights", namely the right to prohibit the creation 
creator changed without that person's consent (Hughes, J.,1988: 40-42).

The idea of the IPR that emerged and developed in the West of the Roman empire make room for the emergence of the idea. Moreover, in the hands of the modern western philosophers, especially John Locke, whose theory of natural law is rationalized the idea, the idea of the absolute ownership is then emerge and be recognized. The history of the emergence of the concept of Intellectual property rights can be read in Vaughan, Richard 'Defining Terms in the Intellectual Property Protection Debate: Are the North and Shouth Arguing Past Each onther when say' Property '? Locken, Conpusian, and Islamic Comparison 'in, ILSA journal. h.6-8. [Http: /www.unsulaw. nova.edu/].

The issue of property began in the 13th century in a line with development of the human rights concept. Developing human rights come up when the Renaissance (Aufklarung) occurs, followed the industrial revolution in England, and the political revolution in France. Further, as implication of the discovery (invention) conducted by Western scientists righs the concept of intellectual property was developed from the West, which begins patents, copyrights, and then grow until reaching its modern form it is today.

Moral doctrine which is based on natural law adopted by IPR regimes to provide individual protection of IPR owners that rights are not violated by others. Indeed, the doctrine of natural law is broader than simply protecting individuals IPR owners, because the doctrine has also applied to protect other parties, including local and traditional communities over their traditional knowledge. Approach moral foundation upon demand to protect IPRs of this emphasis on honesty and fairness. If a person's attempt to steal without getting prior approval it will be seen as an act of dishonest and unfair. Therefore, the ownership of IPRs, including in human rights as individuals who thought, then the value of communalism must be ignored to recognize and reward the individuality.

As the development of IPR, since 1883 at the international level had been appeared various international agreements in the field of IPR, as the following table (JICA Team, 2003: 2), explanation of each convention can be read on pages 6-8, JICA TEAM, 2003. 
THE INTERNATIONAL CONVENTION IN THE FIELD OF IP/IPR

\begin{tabular}{|c|c|c|c|c|}
\hline YEAR & GENERAL & COPY RIGHTS & MARK & PATENT \\
\hline 1883 & $\begin{array}{l}\text { Paris } \\
\text { Convention }\end{array}$ & & & \\
\hline 1886 & & $\begin{array}{l}\text { Bern } \\
\text { Convention }\end{array}$ & & \\
\hline 1891 & & & $\begin{array}{l}\text { Madrid } \\
\text { Agreement }\end{array}$ & \\
\hline 1952 & & \begin{tabular}{l} 
Copyright \\
Convention \} & & \\
\hline 1961 & & $\begin{array}{l}\text { Rome } \\
\text { Convention: } \\
\text { Intemational } \\
\text { Convention for } \\
\text { the Protection of } \\
\text { Performers, } \\
\text { Producers of } \\
\text { Phonograms and } \\
\text { Broadcasting } \\
\text { Organizations }\end{array}$ & & \\
\hline 1967 & $\begin{array}{l}\text { Convention on } \\
\text { the } \\
\text { Establish-ment } \\
\text { of WIPO }\end{array}$ & & & \\
\hline 1970 & & & & $P C T$ \\
\hline 1994 & TRIPS & & Trademark & \\
\hline
\end{tabular}
\end{tabular}




\begin{tabular}{|l|l|l|l|l|}
\hline & Agreement & & Treaty & \\
\hline 1996 & & WIPO & \\
& & $\begin{array}{l}\text { Copyright } \\
\text { Treaty }\end{array}$ & \\
& & & \\
\hline
\end{tabular}

TRIPS Agreement stands for Agreement on Trade Related Aspects of Intellectual Property Rights. This TRIPs clarifies the status of IPR protection as an issue related issues in the field of trade. The aim is to provide IPR protection and rights enforcement procedures by implementing measures towards a healthy trade. Part II of the TRIPS Agreement governing the object of widespread IPR, namely: copyright and related rights; brand; geographical indications; industrial design; patent; layout designs of integrated circuits; and the protection of trade secrets. On the other hand, this agreement also regulates the prohibition of unfair competition practices and licensing agreements.

At the end of the 20th century until today, IPRs became more serious issue because it is associated and is attached to the economic interests, which in the Western concept of a work is an economic advantage (capital). When the economic aspects of IPR disrupted, the Western countries will make every effort to encourage the implementation of the rules on intellectual property in any country. Then it is predictable, because Western countries are rights holders, they are very concerned with the enforcement. In contrast, the Western have to convince the East that the intellectual property rights it is something that is important to balance the economy.

Towards the free trade era, IPR issue has become a strategic issue. The existence of economic globalization, especially in trade and industry also means the globalization of Intellectual Property Rights. This resulted in developing countries will be subject to the application of intellectual property rights belong to the developed countries. Based on the results of UNESCO research experts that developed countries have marched to prioritize the protection of Intellectual Property Rights. Thus, IPR has a very important role in the international world. Therefore, every country is obliged to protect human creativity to further 
encourage progress in the areas of science and art. Indonesia has no other choice but to be involved in areas of the global economy provides an important role in IPR.

TRIPs Agreement of WTO clarified the position of IPR protection as an issue related to trade sectors, aiming to provide IPR protection and procedures of rights enforcement by implementing measures towards a fair trade. TRIPs Agreement uses the principle of full conformity or full compliance as the minimum condition for the participants, this means that the participating countries are required to bring national legislation on IPR fully to international treaties on IPR.

After elaboration on the theory and development of IPR protection in the milestone of history, then there are several theories that underlie the need for IPR protection, as written Robert M. Sherwood (Robert M. 1990), namely:

\section{a. Reward theory}

This theory has a very deep meaning in the form of recognition of the intellectual work which has been produced by someone so that the inventor / creator or designer should be rewarded as a counterweight to the efforts of creativity in finding / creating the intellectual works.

\section{b. Recovery theory}

This theory is synchronic with the principle that the inventor / creator / designer who has spent time, cost and effort in producing intellectual works must regain what has been sacrificed

c Incentive theory

This theory is in a line with theory of reward, linking the development of creativity by providing incentives for inventors / creators or the designer. Based on this theory, incentives needs to be given in order to attempt any useful research activity ahead.

d. Risk theory

This theory recognizes that IPR is a work with risks, for example, research to the discovery of a vaccine against viral diseases would be pose a risk to the life of the researcher / inventor, in fact, he has spent much cost, time and effort as well.

e. Economic growth stimulus theory

This theory recognizes that IPR protection is a tool of economic development. The 
purpose of economic development is the construction of a system of effective protection of IPR.

Furthermore, Anthony D'Amato and Doris Estelle Long (D'Amato, Anthony \& Doris Estelle Long, 1997) theorized IPR protection as follows (Ranti Fauza Mayana, 2004: 45).

\section{a. Prospect theory}

This theory is a theory of IPR protection in the field of patents. In the case of an inventor find great discovery glance not so great benefits, but then there are others who develop the invention into a finding useful and contain innovative elements, the first inventor of this theory will get legal protection on the findings of the first discovery of such. In this case the first inventors to obtain protection under the assumption that the development of these findings by the then only the application or the application of what they find first.

b. Trade secret avoidance theory

According to this theory, if patent protection does not exist, firms will have great incentive to protect their inventions through a trade secret. The company will invest excessively in "hiding" his discoveries by investing excessive. Based on this theory, patent protection is an alternative that is economically very efficient.

\section{c. Rent dissipation theory}

This theory is intended to provide legal protection to the first inventor for its findings. The first inventors to be protected from the resulting findings although then the invention will be enhanced by other parties then intend to patent the invention has been perfected. If the inventions that have improved the patented, the findings of the original inventors will compete in the market. Rent dissipation theory states that an invention can be granted a patent if the invention itself suggests ways in which it can be made commercially and more useful.

Then, the basic philosophical IPR regimes are economic reasons. Individuals have been sacrificing power, time, mind even charge for the sake of a work or invention that is useful for life. Rationality to protect the capital investment must be accompanied by granting exclusive rights to the individuals concerned to be able to exclusively enjoy the results if he 
thought it was. Aristotle's teachings also have described above arguments in an attempt to create justice. One justice, known in theory is distributive justice. Distributive justice is justice that gives to each person according to his services section. That is not justice that is based on similar numbers but proportionality.

In addition, there is the economic theory known as the theory of bargaining can be used as material discussions required in the urgency of the practice of setting IPR in order to achieve a balance between the economic interests of individual and holders of intellectual property rights, as well as the balance of the national economic growth rate caused by implementation or exploitation of IPR itself. In addition, the Labour Theory also been raised about the importance of IPR protection, namely: "Patent and other types of intellectual property rights are intended to Prevent people from commercially Exploiting ideas or inventions without fair compensation to the originators. The concept comprises two competing social objectives: the need to encourage technical innovations and the need to disperse the benefits of that innovation throughout society.

IPR regimes also adopted and developed the theory of utilitarian Jeremy Bentham. This theory explains that the law established in order to provide the benefits and happiness for most citizens. According to utility theory, the law must be able to provide as many benefits and happiness to most people. Darji Darmodiharjo and Sidharta describe the views Jeremy Bentham as follows.

The Bentham's view actually moved from its strong concern for the individual. He wants law can provide a guarantee of happiness to individuals, rather than directly to the community as a whole. Nevertheless, Bentham does not deny that in addition to individual interests, society interest needs to be concerned. To avoid clashes, individual interests in the pursuit of happiness as much as possible needs to be restricted. If not, there will be what is called a homo homini lupus (man becomes a wolf to another man).

According to the utilitarian theory, the formation of legislation in the field of IPR is a form of protection so that people get the benefit of it. This is in the context of economic development, especially in the field of IPR into reward theory. Reward theory postulates that when creative individuals were given incentives in the form of exclusive rights, then this will 
stimulate other individuals to create, in other words, the IPR regime is a form of compensation and encouragement for people to create. It can benefit people in the long term. Through the innovative use, it expected to ultimately enhance the level of information and innovations that are available in the community. By contrast, in some developing countries, the natural right is irrelevant because the property even has a social function and belong together. This means that the public can have a natural right over an invention or inventions made either by individuals or through group cooperation. The values underlying philosophy of individual ownership to a work of human creativity both in the field of science, literature, and art is a western cultural values manifest in the legal system.

Conception of civilized society suggest that people can have opinion that they may posses for purposes that are beneficial for them, nothing they have found and have for its own purposes, what they have created with its own power, and what they have acquired through a public order and the economy. This principle is called suum cuiqe tribuere (objects obtained by a person are his possessions). However, despite the guaranteed freedom enjoyed principles upon still must share it with the concept of state property (res publicae) and the concept of public goods (res communes) .Most experts believe that excessive monopoly of an IPR could undermine the development of science and human civilization. Instead of science is the property of the progress of humanity, then human beings can not fully monopolize a user any right sense.

From the description seen the idea that an intellectual work produced by a person on the basis of intellect, either inventions or other intellectual property needs to be protected in order to prevent all forms of commercial exploitation by others without fair compensation to individuals / parties who produce intellectual work. The concept also implies to support two social purpose, namely the need to stimulate new inventions on the one hand, and on the other hand the need to disseminate the intellectual work to meet the needs and interests of the community.

\section{E. CLOSING}

Based on the discussion, it can be concluded that the theory of natural law (the natural right) is still relevant to be used as a moral and philosophical foundation for the protection of IPR that 
is an individual property rights. Moral doctrine which is based on natural law was adopted by the IPR regime to protect the individual owners of IPRs in order their rights are not violated by others. However, the actual doctrine of the natural law is broader than simply protecting individuals IPR owners, because the doctrine was also to be applied to protect other parties, including local and traditional communities over their traditional knowledge. Approach demands a moral foundation to protect IPRs of this emphasis on honesty and fairness. If stealing someone's business / creation / work / invention without getting prior approval it will be seen as an act of dishonest and unfair. Therefore, the ownership of IPR included in the exercise of human rights as an thinking individual, then the value of communalism must be ignored to recognize and reward the individual. The issue of property that started in the 13th century parallel with development of the concept of human rights, which then in modern times that provisions can be seen in the provisions of Article 27 paragraph (2) Universal Declaration of Human Rights.

\section{BIBLIOGRAFI}

\section{Books:}

Adami Chazawi. 2007. Tindak Pidana Hak Atas Kekayaan Intelektual (HaKI): Penyerangan Terhadap Kepentingan Hukum Kepemilikan dan Penggunaan Hak Atas Kekayaan Intelektual (Intellectual Property Rights (IPR): Assault on Legal Interest Ownership and Use of Intellectual Property Rights). Malang: Bayumedia Publishing.

Adrian Sutedi. 2009. Hak Atas Kekayaan Intelektual (Intellectual Property Rights). Jakarta : Sinar Grafika

Akira Okawa. 1997.Major Provisions under WTO-TRIPs Agreement. Paper. Industrial Property Rights Training Course for Management. Tokyo : JIII \& AOTS.

----------. 1994. Kompilasi Undang-Undang Republik Indonesia di Bidang Hak Kekayaan Intelektual (Compilation of the Law of the Law of the Republic of Indonesia in the Field of Intellectual Property Rights). Tangerang : Ditjen HKI Depkeh \&HAM RI dan JICA

1997. Agreement on Trade Related Aspect of Intelectual Property Rights (TRIPs Agreement) (1994). GENEVA : WIPO.

.1994. Indonesia's Law Number 7 Number 1994 on The Ratification of Agreement (Persetujuan Pembentukan Organisasi Perdagangan Dunia). Jakarta: Sekretariat Negara RI. 
. 2001. Doha WTO Ministerial 2001: Ministerial Declaration. Adopted on 14

November 2001 Error! Hyperlink reference not valid.

Org/english/thewto_e/minist_e /min01_e/mindecl_e.htm. [28 Nopember 2012]

Arthur R. Miller dan Michael H. Davis. 1983. Intellectual Property Patents, Trademarks, and Copyright in A Nutshell. St. Paul, Minnesota : West Publishing Co

AusAID. 2001. Intellectual Property Law (Patent and Design). Jakarta: Asian Law Group.

A. Zen Umar Purba,. 2001 "Traditional Knowledge Subject Matter For Which Intellectual Protection is Sought”. Paper. WIPO Asia-Pacific Regional Symposium on Intellectual Property Rights, Traditional Knowledge and Related Issues, October 17 to 19. Yogyakarta: WIPO \& DGIPR.

Bouchhoux, Deborah E. 2001. Protecting Your Company's Intellectual Property: A Practical Guide to Trademarks, Copyrights, Patents \& Trade Secrets. New York : Amacom.

Budi Agus Riswandi dan M. Syamsuddin. 2005. Hak Kekayaan Intelektual dan Budaya Hukum (Intellectual Property Rights and Legal Culture),. Jakarta: PT Raja Grafindo Persada

Casson, D.J. 2011. Liberating Judgement: Fanatics, Skeptics, and John Locke's Politics of Probability. New Jersey: Princeton University Press.

Cita Citrawinda.2003. Hak Kekayaan Intelektual-Tantangan Masa Depan (Intellectual Property Rights-Future Challenges). Jakarta: Badan Penerbit Fakultas Hukum Universitaas Indonesia

D’Amato, Anthony \& Doris Estelle Long. 1997. International Intellectual Property Law. London: Kluwer Law International.

Darji Darmodiharjo \& Sidharta. 2006. Pokok-pokok Filsafat Hukum, Apa dan Bagaimana Filsafat Hukum Indonesia (Principles of the Legal Philosophy, What and How Indonesian Law). Jakarta: PT Gramedia Pustaka Umum.

Dutfield, G. 2003. Intellectual Property Rights and the Life Science Industries: A $20^{\text {th }}$ Century History.. Hampshire: Ashgate Publishing Limited.

Endang Purwaningsih. 2005. Perkembangan Hukum Intellectual Property Rights Kajian Hukum terhadap Hak atas Kekayaan Intelektual dan Kajian Komparatif Hukum Paten (Legal Development of Intellectual Property Rights of Legal Study on Intellectual Property Rights and Comparative Study of Patent Law). Bogor: Ghalia Indonesia 
Elsi Kartika Sari dan A Simanunsong. tt. Hukum Dalam Ekonomi. Jakarta: Grasindo. http://books.google. co.id. [4 Desember 2012].

Graham Dutfield.2004.Intellectual Property, Biogenetic Resources and Traditional Knowledge. UK:. Earthscan

Granstrand, O.1999. The Economics and Management of Intellectual Property: Towards Intellectual Capitalism. Cheltenham (UK): .Edward Elgar Publishing Limited

Hendra Tanu Atmadja,. 2003. Hak Cipta Musik atau Lagu (Music or Song Copyright). Jakarta : Fakultas Hukum

Hoiberg, Dale H, ed. 2001. “Human rights : Historical Develovment”. Encyclopaedia Britannica. CD ROM Edition.

H Milne. 1988. Resisting Protectionism: Global Industries and the Politics of International Trade. Princeton:Princeton University Press.

Hughes, J. 1988. “The Philosophy of Intellectual Property”. Georgetown Law Journal, 77(287 )

Ida Susanti dan Bayu Seto ed. 2003. Aspek Hukum dari Perdagangan Bebas, Menelaah Kesiapan Hukum Indonesia dalam Melaksanakan Perdagangan Bebas, Percikan Gagasan tentang Hukum IV (Legal Aspects of Free Trade, Reviewing the Legal Preparedness of Indonesia in Implementing Free Trade, Sparking the Idea Of Law) . Bandung: Citra Aditya Bakti.

Ignatius. Haryanto. 2004. "Menembus Kebekuan Rezim HKI (Penetrating the Freeze of the Regime of Intellectual Property Rights)". Kompas, Minggu, 10 Oktober 2004

. 2005. "Keluar dari Rumah Kaca: Problematika Memandang Masalah Hak atas Kekayaan Intelektual (Problematic Viewing Intellectual Property Rights Issues)”. Jurnal Seni Pertunjukan Indonesia Tahun XIII - 2005.

Insan Budi Maulana. 2007. "Paten Dalam Bingkai AL-Qur'an : Pendekatan Sejarah dan Hukum”. Pidato Pengukuan Guru Besar. Jakarta: Fakultas Hukum Krisnadipayana.

John Braithwaite dan Peter Drahos.2000. Global Business Regulation. New York: Cambridge University Press.

JICA Team.2003. Capacity Building Program on the Implementation of the WTO Agreements in Indonesia (TRIPS COMPONENT), Training Material on Enforcement of Intellectual Property Rights. Jakarta: DGIPR.

Locke, J. 2004. The Second Treatise of Government. USA: Barnes \& Noble Publishing, Inc. 
Lionel Bently \& Brad Sherman. 2004. Intellectual Property Law. New York: Oxford University Press Second edition. .

Muhamad Djumhana dan R. Djubaedillah.1996. Hak Milik Intelektual (Sejarah Teori dan Prakteknya di Indonesia). Bandung: Citra Aditya Bakti. ..2006. Perkembangan dan Teori Perlindungan Hak Kekayaan Intelektual. Bandung: Alumni

New York Times. 1999, 9 April.

Otje Salman dan Anton F. Susanto, 2005. Teori Hukum : Mengingat, Mengumpulkan dan Membuka Kembali. Bandung : PT. Refika Utama. Cet. Ke-2.

Ok Saidin. 2004. Aspek Hukum Hak Kekayaan Intelektual (Intelectual Property Rights. Jakarta: PT Raja.

Peter van Den Bossche.2005. The Law and Policy of The World Trade Organization Text, Cases and Materials. UK: Cambridge University Press.

Prasetyo Hadi Purwandoko. 2010. “Pokok-pokok Hak Kekayaan Intelelktual”. Makalah. Disampaikan dalam Workshop Technical Assistance Hak Kekayaan Intelektual, Selasa - Rabu, 21-22 September 2010, di AULA Fakultas Pertanian Universitas Palangkaraya.

Priharniwati. 2004. "Peranan Direktorat Jenderal Hak Kekayaan Intelektual (Ditjen HKI) dalam Pembangunan EkonomI". Makalah. Disampaikan pada Seminar Nasional Hubungan antara Penegakan Hukum HKI dan Pembangunan Ekonomi, tanggal 28 September, di Hotel Sheratom Bandung.

Rachmadi Usman. 2003, Hukum atas Kekayaan Intelektual. Bandung: Alumni

Ranti Fauza Mayana. 2004. Perlindungan Desain Industri di Indonesia. Jakarta: PT Gramedia Widiasarana Indonesia.

Richard Burton Simatupang. 1996..Aspek Hukum dalam Bisnis. Jakarta: Rineka Cipta.

Robert Cooter dan Thomas Ulen. 2000. Law and Economics. Third Edition. USA: Addison-Wesley

Roscoe Pound,. 1996. Pengantar Filsafat Hukum. Jakarta : Penerbit Bharatara

R Went.1997. "Globalization: Myths, Reality and Ideology: The EU in a Globalized World". 26(3) Int'l J. Political Economy

Schwabach, A. 2007. Intellectual Property. California: ABC-CLIO, Inc. 
Sherwood, Robert M. 1990. Intellectual Property and Economic Development: Westview Special Studies in Science Technology and Public Policy. San Francisco: Westview Press Inc.

Sri Redjeki hartono. 2007. Hukum Ekonomi Indonesia. Malang: Bayu Media.

Tim Lindsey. dkk. 2005. Hak Kekayaan Intelektual Suatu Pengantar. Bandung: PT Alumni.

Zaid Hamzah. 2007. Intellectual Property Law \& Strategy. Singapore: Thomson/ Sweet\&Maxwell Asia.

\section{Internet:}

A. Zen Umar Purba. 2001. "Sistem Hak Kekayaan Intelektual dan Kaitannya dengan UKM" Makalah. Disampaikan pada acara Peresmian SME Center dan Panel Diskusi, Jakarta, 7 November 2001. http://www.dgip.go.id/article/ articleview /60/1/15/[20 April 2013].

. 2001. "Perlindungan dan Penegakan Hukum HKI". Makalah. Disampai-kan pada Acara Pelatihan Teknis Fungsional Peningkatan Profesionalisme, Diselenggarakan oleh Pusdiklat Mahkamah Agung RI, Makassar, 20 November 2001. http://www.dgip.go.id/article/articleview/60/1/15/. [10 Nopember 2012].

.2002. "Sistem Haki Nasional dan Otonomi Daerah" . Makalah. Di-sampaikan pada acara seminar nasional, Implementasi Undang-Undang Desain Industri dan Merek, diselenggarakan bekerjasama Fakultas Hukum Universitas Sam Ratulangi, Fakultas Hukum Universitas Manado, Yayasan Klinik HaKI, JIII, APIC, Asosiasi Alumni JIII. Indonesia, didukung oleh JPO dan Ditjen HaKI Departemen Kehakiman dan HAM, Manado, pada tanggal 18 Februari 2002. . $\underline{\text { http://www.dgip.go.id }}$ /article/articleview/60/1/15/. [15 April 2013].

.2002. Peta Mutakhir "Hak Kekayaan Intelektual Indonesia” Makalah. Disampaikan di Jakarta, 29Januari 2002. http://www.dgip.go.id/article/ articleview/60/1/15/ [20 April 2013]

Andy Noorsaman Sommeng .2002. "Relevansi Relevansi Kekayaan Intelektual terhadap Usaha Kecil danMenengah “. Naskah Power Point. Disampaikan dalam Sosialisasi HKI bagi Aparatur Pemerintah Daerah Propinsi, Kabupaten/Kota yang Membidangi Koperasi Dan Usaha Kecil dan Menengah Makassar, 21 Oktober 2002 . http://www.dgip.go.id/ article/ articleview/60/1/15/ [20 November 2012].

Anonim. Thirty Years War. http://www.historylearningsite.co.uk/thirty_years_war.htm. [5 
September 2011].

ILSA journal . [http:/www.unsulaw. nova.edu/].

Khaerul Hidayat Tanjung,. 2007. Filosofi Hak Kekayaan Intelektual. .Error! Hyperlink reference not valid.. com /filosofi_hak_kekayaan_intelektual. Html. [10 Oktober 2012].

Rousseau, J.J. 2004. The Social Contract or Principles of Political Right. . http://books.google.co.id/. [26 April 2011]

http//:www.dgip.go.id

http://www.wipo.int/about-ip/en/. 2009. "What is Intellectual Property?”. [21 Oktober, 2012]. 